on record. I have sent the heart for preservation to the Anatomical Museum at Cambridge.

Wisbech.

\section{CHRONIC SENILE DIARRHCA, PROBABLY FROM DEGENERATION OF THE INTESTINAL WALLS.}

By A. J. B. DUPREY, M.R.C.S. ENG., L.R.C.P. LOND.

DEGENERATION is not uncommonly in persons past middle life the source of various uncomfortable symptoms, and in a tropical country such as that of Trinidad, where old age is to some extent premature, we may expect to find senile troubles manifested sooner than in colder climates. Not unfrequently we meet with cases of diarrhœa in persons approaching or beyond sixty years of age, which can only be ascribed to degeneration of the intestinal walls, due either to albuminoid disease or to some perverted action presumably associated with degeneration. The patient whose illness I am about to describe was a female fifty-six years of age and was a member of a family one of whom I had been attending only a few days previously for poisoning by alkaline ptomaines, an accident which not unfrequently occurs in these parts. She had al ways enjoyed good health until about $t$ welve months ago, when a small tumour, the nature of which was not propesly ascertained, was removed from her nose. About vine months ago she observed an undue looseness of the bowels, since which time she had had three attacks of diarrhoea, each of them more severe than the precering one. The present attack was therefore the fourth. When I first saw her, her temperature was $101 \cdot 2^{\circ} \mathrm{F}$. and her pulse 84 ; the heart's area was normal ; the sounds were very feeble, bat no abnormality in the rhythm could be detected; there was dimness of sight and well-marked arcus senilis of both eyes ; the tongue was slightly furred. The patient retched very often and cccasionally vomited; she also complained of great pain in her abdomen; it was tender on pressure, and she passed fluid evasuations at intervals of twenty minutes or half an hour. As there had been cases of ptomaine poisoning in the house I considered this illness to be of the same kind, and orojered ;brandy milk with soda water, and a mixture containing bismuth sub-carbonate and nepenthe. During the next twenty-four hours the diarrboea was less frequent, but symptoms of cardiac failure were developid, so urgent that death appeared to be imminent. The patient had repeated attacks of fainting, sometimes at intervals of fifteen minutes; her skin was almost icy cold, her lips were livid, and the pulse at the wrist was scarcely perceptible. I was at this time informed that she had suffered from fainting fits during her previous attacks of diaurboa, although inever so seriously as at present. Taking into consideration the marked degeneration of her corneal tissue shown by the arcus senilis, her dimness of rision, the failure of the circulation, and the chronic diarrhoea, I came to the conclusion that degeneration resulting from senile changes might have originated her troubles. Artificial warmth was supplied by hot-water bottles and flannels wrang out of hot water; a mixture containing five drops of tincture of digitalis and twenty drops of spirit of nitrous ether was given every four hcurs and improvement commenced immediately. When she was able to walk about the room five drops of tincture of strophanthus were given three times a day in place of the digitalis; and except for a slight giddiness on getting up in the mornirg she has satisfactorily recovered. There can be little doubt about either the degeneration of her heart muscle or the prompt efficacy of the digitalis in strengthening the heart's action, and thereby improving the circulation.

Port of Spain, Trinidad, West Indies.

\section{A CASE OF RECURRENT SCIRRHUS OF THE MALE BREAST.}

By Selby W. Plummer, M.D., B S. Durh., HONORARY SURGEON TO THE DURHAM COUNTY HOSPITAL.

A MAN, aged thirty-nine years, was admitted in March of this year under my care into the Durham County Hospital. He gave the following history. Eight years previously he had noticed a small lump in his right breast, which slowly increased for four years. Although painless itself, shooting pains ran down the right arm from it. In January, 1893, this tumour was removed by Dr. Tough of Crook, County Durham. In 1895 the patient again noticed a hard nodule on the upper and outer part of the right chest, which gradually increased, and similar shooting pains were felt down the arm. This growth was froely excised and proved to be a typical scirrhous carcinoma invading a gland. Dr. Tough, having preserved the specimen which he excised, kindly sent it to me for examination, stating that the size on removal was about that of a pigeon's egg, and sections of this specimen showed it to be a scirrhous carcinoma of the mammary gland.

Notes of cases of cancer in the male breast are, I think, always interesting. It should be added that two of this patient's cousins on the female side died from cancer; in one the growth was located in the breast ard in the other in the rectum. There is no cther family history of predisposition.

Durham.

\section{a ditlitror}

\section{of}

\section{HOSPITAL PRACTICE, BRITISH AND FOREIGN.}

Nulla autem est alia pro certo noscendi via, nisi quamplurimas et morborum et dissectionum historias, tum aliorum tum proprias collectas habere, et inter se comparare-Mokgagar De Sed. et Caus. Morb., lib. iv. Proomium.

\section{NETLEY HOSPITAL.}

A CASE DEMONSTRating THE application OF THE ROENTGEN RAYS TO MILITARY SURGERY.

(Under the care of Surgeon-Colonel Stevenson and Surgeon-Major H. R. WHITEHEAD )

THE localisation of bullets has always been a matter of great difficulty, and the majority of the clder surgeons refused to attempt the removal of a bullet if it were deeply placed; and in this they were fally justified, for the diffculties and dangers of deep dissections were so great that the patient as a rule ran less risk if nothing were done. By the electrical method employed to a slight extent of late years somewhat vague information could be obtained as to the whereabouts of a deeply seated bullet, but it was not until the introduction of the Roentgen rays that a surgeon could be quite certain of the exact position of the projectile, and in no case is the surgical value of the $x$ rays more obvious than in this. The opacity of a body consisting of lead is so much greater than that of bone that the shadow cast by it is readily discernible, even when the leaden body is entirely surrounded by ossecus tissue. It will be seen in the description of the case that the exact position of the metallic body was ascertained by taking two skiagraphs from different aspects.

The patient was a private in the 1st Battalion Gordon Highlanders, and had received a bullet wound jast below the left knee on April 3rd, 1895, at the battle of Malakand Pass, Chitral Expedition. He was admitted to hospital and the wound explored, and he stated that tbree pieces of lead were removed, although this statement was not supported by documentary evidence. The wound eventually healtd up, and the man was sent home and admitted to Netley Hospital on April 28ch, 1895. On bis admission there he had a firmly cicatrised wound two and a half inches in length situated just below the level of the tubercle of the left tibia on the inner side of the leg. The bone was not enlarged, and pressure on the cicatrix was not painful. He cow plained, however, of pain deep in the bone at times and lameness, and he fancied that the bullet or some part of it remained in the bone. With the assistance of Surgeon-Captain Aldridge skiagraphs were taken of the leg in two positions-the first from the anterior aspect and the second from the inner surface. A spherical bullet was at the same time fastened against the limb, in order that its image might appear in the picture and might assist in determining whether a bullet was embedded in the bone or not. Both skiagraphs showed a disc of metal, he conclusion, therefore, being that the bullet was present 